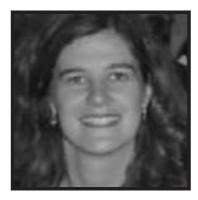

\title{
The Inquiry-Based Science Pedagogy Debate
}

\author{
Marguerite Comley, Lower Canada College
}

\section{ABSTRACT (Press Here for Sound)}

The science curriculum reform by Quebec's Ministère de l'Éducation, du Loisir et du Sport (MELS) mandates the use and evaluates the performance of students in activities that would be defined as inquiry-based. This article discusses the importance of using inquiry-based laboratory experiments and assesses the challenges that teachers face when using this type of pedagogy.

ast March I attended the annual National Science Teachers' Association conference in Boston. At the conference store, I eagerly picked up and bought the book Teaching Inquiry-Based Chemistry by Joan GallagherBolos and Dennis Smithenry (2004). As I had been teaching chemistry for ten years and have struggled with designing inquiry-based laboratory experiments that linked directly to the curriculum, I was excited to explore any new ideas.

As I flipped to the first chapter and read the description of the inquiry-based experiment that these teachers had created for their grade 12 chemistry classes, I quickly became disillusioned by the content and left the rest of the book unread. The inquiry-based activity had the class perform the following task for the duration of one month near the end of the school year: "In a cost-effective and creative manner, your company is to produce two pounds of packaged, quality soap that meets and appeals to the consumers' demands of a specific soap market" (Gallagher-Bolos \& Smithenry, 2004, p. 15). The teachers organized the students into groups based on different jobs required to meet the goal: research scientists, engineers, accounting, marketing, advertising, public relations, plant manager, science supervisor, business supervisor and quality control supervisor. Gallagher-Bolos and Smithenry presented 
the students with clear objectives and well-defined tasks. They also gave clear instructions to other teachers running a similar course about the role of the teacher: to act as facilitator and to limit intervention in class decisions.

Why did I dismiss this book so quickly, when it had received accolades from well-respected college educators in chemistry? My first reaction to this soap project was that there was very little science content covered in the month-long project. While some students worked on the production of soap, others were involved in more project-management types of roles. This project integrated many work and social team-building skills into the study of soap. From my own experience, I have found that inquiry-based laboratory sessions are often time consuming for the amount of content the students are able to cover. For the past number of years, the province of Quebec's Ministère de l'Éducation, du Loisir et du Sport (MELS) (2008) has been implementing a new educational reform. This new curriculum mandates the use of inquiry-based learning activities to study the curriculum content. Students are encouraged from grade seven through eleven to study science using experiments and models that they have developed on their own or in a group. Students are expected to be evaluated on their competency to seek solutions to scientific problems. But is inquiry-based pedagogy an effective and efficient way to learn about science and evidence-based scientific inquiry?

In this paper I will define inquiry-based education, and I will discuss the advantages of inquiry-based learning activities and challenges to implementing this approach in the context of the Quebec science curriculum. Three theoretical principles on how students learn science, developed by the (American) National Research Council (Donovan \& Bransford, 2005) provide the framework for my analysis of the arguments for and against inquiry-based pedagogy.

\section{Inquiry-Based Education}

Inquiry-based science is not a new phenomenon. As early as 1910 , John Dewey discussed the importance of teaching science through scientific inquiry rather than the instruction of scientific facts (Olson \& Loucks-Horsley, 2000). Joseph Schwab, a science educator in the 1960 s also emphasized the role of experimentation in the development of scientific understanding. The National Science Education Standards defines inquiry-based education as the following,

Inquiry is at the heart of the National Science Education Standards. The Standards seek to promote curriculum, instruction, and assessment models 
that enable teachers to build on children's natural, human inquisitiveness. In this way, teachers can help all their students understand science as a human endeavor, acquire the scientific knowledge and thinking skills important in everyday life and, if their students so choose, in pursuing a scientific career (Olson \& Loucks-Horsley, 2000, p. 6).

The guidelines for teaching science inquiry follow the thought processes of many scientists. They initially create a question from their background knowledge.To analyze this question they propose a hypothesis to explain the phenomenon. They then design an investigation to test their hypothesis. They gather data and they propose an explanation to the problem based on an evaluation of the evidence. They consider other explanations and compare their ideas to the other models. The scientist then communicates his/her findings and continues to test the explanation. Student objectives for inquiry-based activities at the high school level from the National Science Education Standards are listed in the table below. Teachers act more as facilitators rather than providers of information in inquiry-based activities.

\section{Content Standard for Science as Inquiry: Fundamental Abilities Necessary to Do Scientific Inquiry}

Grades 9-12

- Identify questions and concepts that guide scientific investigations.

- Design and conduct scientific investigations.

- Use technology and mathematics to improve investigations and communications.

- Formulate and revise scientific explanations and models using logic and evidence.

- Recognize and analyze alternative explanations and models.

- Communicate and defend a scientific argument.

(Olson \& Loucks-Horsley, 2000, p. 19)

\section{How Students Learn Science}

The (American) National Research Council produced a series of articles analyzing how students learn in science, mathematics and history. Donovan and Bransford's (2005) analysis led them to propose three general principles of learning, particularly in the sciences: engaging prior understanding, the essential role of factual knowledge, and the importance of self-monitoring for understanding. 


\section{Principle \#1: Engaging Prior Understandings}

"Students come into the classroom with preconceptions about how the world works. If their initial understanding is not engaged, they may fail to grasp the new concept" (Donovan \& Bransford, 2005, p. 1). Many of our everyday experiences create misconceptions about specific concepts in science. For example, many students in chemistry believe that an ice cube would melt faster in a salt solution than in distilled water. They would give the evidence that we put salt on the roads in the winter to melt the ice. Students' prior knowledge understanding of the concept must be addressed in order to evoke a conceptual change.

\section{Principle \#2:The Essential Role of Factual Knowledge and Conceptual Frameworks in Understanding}

This principle places an emphasis on the subject matter, the understanding of the material and the links between content and comprehension. In science it is the "knowledge of what it means to do science" (Donovan \& Bransford, 2005, p. 402). This idea stresses the importance of scientific inquiry that enables students to link observations with the desired concepts. If students study the melting process of the ice cube in both salt water and distilled water, they find that the ice cube in the salt water melts at a slower rate. The students can then test theories that they may have through experimentation. The process of experimenting may help them learn more about the concept. Factual knowledge in the area of study is imperative to this principle. Students must have enough background knowledge so that they can produce some reasonable theories and ways to test their ideas.

\section{Principle \#3:The Importance of Self-Monitoring}

For students to improve their understanding of a concept, they must be aware of how they learn and remember information. In science, concepts are abstract and often difficult to comprehend. In chemistry, for example, models are often used to explain the structure of molecules at the atomic level. When using models, students must be aware that there are limitations to these models. Students need to reflect on their own understanding and comprehension. Teachers need to "help 
students compare their personal ways of knowing with those developed through centuries of scientific inquiry" (Donovan \& Bransford, 2005, p. 411).

\section{The Advantages of Inquiry-Based Science Activities}

Inquiry-based science learning is active learning. Students take on the role of the scientist to develop their understanding of the scientific method. Evidence in the literature of the advantages of using inquiry-based laboratories is widespread (DeHart-Hurd, 1997; Gallagher-Bolos \& Smithenry, 2004; Donovan \& Bransford, 2005). Inquiry experiences enable students: to build on their prior knowledge, to develop understanding and attain a high level of content or conceptual understanding. In addition, this pedagogy allows for the integration of the science curriculum into societal issues and gives students their own voice and self-awareness in the classroom.

Students often enter the science classroom with preconceived ideas about science and their physical world. Many of these ideas have come from their own observations of their environment around them. Students are able to address preconceived ideas about scientific concepts through inquiry-based laboratory experiments. "Simply telling students what scientists have discovered, for example, is not sufficient to support change in their existing preconceptions about scientific phenomena" (Donovan \& Bransford, 2005, p. 398). For example, most students would believe that two objects of the same size but of different masses, such as a 50-g ball and a 5-kg ball, held at the same height would fall at different rates depending on their mass. If students drop these balls from the same height and record the time it takes for the balls to hit the ground, they quickly see that the objects fall at the same rate. If the concept is explained to students but not demonstrated or experienced they may be able memorize the law; however, they may resort back to their faulty preconceptions because they trust their instinct that a heavier object would fall at a faster rate over the newly memorized concept. This idea links directly to the first principles of how students learn. "Learning experiences need to develop from first hand concrete experiences to the more distant or abstract" (Donovan \& Bransford, 2005, p. 512). Students need to see the link from their prior knowledge to the new concept. This link can be facilitated through an inquiry-based lab.

Students need the opportunity to think as scientists. Often in science classes, we tend to "emphasize teaching and learning of science, at the expense of learning about science and to do science" (Bencze \& Di Giuseppe, 2006, p. 336). Bencze and Di Giuseppe argue that we teach scientific facts; however, little time is devoted to scientific inquiry. Many of the laboratory experiments that the students perform in class 
are already developed and written in laboratory manuals. The students follow the set of "recipe-like" instructions and note the observations. In chemistry, it is often particularly difficult to see the connection between the observations and the concept studied. Because most observations in chemistry are indirect (such as a colour change in a reaction), students are challenged to see the link between the observation (colour change) and the concept (evidence of a chemical reaction). These step-by-step laboratory sessions do not fall into the category of inquiry-based ones. These guided laboratory sessions do not allow the student to create, observe and reason on their own. These are key components of the second principle of how students learn science. Students need to see science as "a process of inquiry rather than inquiry time" (Donovan \& Bransford, 2005, p. 405). They need to develop their imagination and reasoning skills. This development will enable them to conceptualize and visualize the models that are developed in science because they have been pushed to create their own models and ideas about a specific phenomenon. A study (Ogan-Bekirouglu \& Sengul-Turgut, 2008) of grade 9 physics students found that they were able to develop higher-level thinking using inquiry-based laboratories. "Results indicated that teaching methods and strategies based on constructivist approach (inquiry based laboratories) helped the students move their epistemological beliefs in physics through upper levels" (p. 1). Students engaged through inquiry-based activities will be pushed to think like scientists. Through this inquiry, they are able to work on their observational, imagination and reasoning skills. This skill development in my opinion will help them reach a higher level of thinking such as conceptualization of the models-an ability essential to understanding science.

DeHart-Hurd (1997) argues that the American national science standards need to be revised for our changing world. He states that students need to see the link between science and real-life situations. The disconnection between the workplace and school is a detriment to science education:

What is required is an assortment of higher level thinking skills a number of which can be developed from a study of science in a work context. These are also skills required of students to achieve economic success in life (p. 10).

Inquiry-based laboratory sessions such as the soap project allow the student to study science using a real-life situation. Inquiry-based laboratory sessions can be used in the development of the integrated curriculum. Scientific discoveries and decisions made by scientists have a huge influence on our society. We cannot study the sciences in isolation; we must integrate societal and economic influences of science in the science classroom. DeHart-Hurd argues for the use of real-life situations in the study of science. 
Since our founding, school science has been taught in the context of America as a producer of new knowledge about the natural world. Today the focus changes to developing learning skills that are essential for a consumer who utilizes science information. This means the subject matter of science is selected for its value in resolving personal, social, and economic problems, and for augmenting our adaptive capacities as human beings (DeHart-Hurd, 1997, p. 80).

Real-life inquiry-based problems allow for true curriculum integration. Take the current environmental and economic crisis as an example. Each decision made to improve our environment requires major economic changes. Giving the content social significance enables students to see the relevance of what they are learning. Students may also discover that the work of scientists is linked to our society.

Tools have meaning only when their usefulness is understood: indeed their meaning lies in what they can be used to do. This means that students should grapple with the problems first and learn to use the tools as they find them helpful (Parsons, 2004, p. 778).

If concepts are repeated, inquiry-based labs allow the student to reinforce knowledge by applying these theories to different situations. This type of activity is a key component of the second principle of learning that states that the linkage of content to concept through different activities reinforces understanding.

“Effective learning requires that students take control over their own learning" (Gallagher-Bolos \& Smithenry, 2004, p. 90). In the soap activity, Gallagher-Bolos and Smithenry found that the students were encouraged to look at their own skills as students and as contributors to the class during their inquiry experience. Students offered positive feedback to being given the opportunity to learn and make decisions independently. One student commented, "I really enjoyed doing this project. It was the ultimate test to see if we could learn and work on our own. Nobody's ever given me that opportunity before. I didn't even know what I was capable of" (Gallagher-Bolos \& Smithenry, 2004, p. 28). The ability to monitor our own capacity to learn is the key component of the third principle on how students learn science. When students take control of their learning situation, they are forced to assess their development, an essential skill to learn.

Inquiry-based activities address all three principles of how students learn. The laboratory sessions enable students to use prior knowledge to study new material 
that is fundamental to addressing preconceptions in science, the first principle. Students who use inquiry-based labs act as scientists, a key component of the second principle. Asking their own questions and reasoning through observations enables students to develop skills that lead to higher-order thinking. Often these activities help integrate other social topics to the sciences. Students are able to see the relevance of the scientific material they are studying. Giving students a chance to work independently forces them to evaluate themselves as learners. This covers the third and final principle of how students learn, that of metacognition, teaching students to take control of their own learning.

\section{The Challenges of Inquiry-Based Science Activities}

Bencze and Giuseppe (2006) studied the implementation of inquiry-based pedagogy in the science department at a school in Ontario whose mandate was to encourage teachers to use inquiry-based, self-directed learning. They found the science department had difficulty carrying out the mandate despite support from its administration.

Why is there resistance by science teachers to use inquiry-based laboratory sessions when the research literature supports this method of teaching as an effective way for students to learn? Bencze and Giuseppe outline a number of challenges and obstacles that teachers must address when they decide to use inquiry-based activities. Three major concerns which impeded the use of inquiry-based laboratory sessions were found to be: the fear of the inability to address the content of the course using this pedagogy, the challenges of designing effective inquiry-based laboratories, and demands for a more traditional approach from the students and parents.

In the past four years the Quebec government has redesigned the science curriculum for grades seven through eleven. One of the primary changes is that the students are to use inquiry-based activities to develop their understanding of the material. Inquiry-based laboratories take time. Rather than giving a twenty-minute didactic lecture on the topic, two or three classes would be necessary to have the students arrive at the same conclusion. While this development would not be considered a waste of time, the curriculum is loaded with content that must be covered. Teachers struggle with the task of covering the intense content list mandated by the government using this more time-consuming teaching process. Bencze and Di 
Giuseppe found the same problem arising in the Ontario school. One teacher voiced the following concerns:

I know that there is a worry and fear [amongst teachers]. There is a brand new curriculum for grade nine and it is chock-full [of content], and [teachers ask,] How is it all going to be covered? And are kids going to be prepared the same as everybody [else]? If kids have to go out there and do it on their own, then how do you know it is getting done? (Bencze \& Di Giuseppe, 2006, p. 349).

Teachers are receiving a mixed message. For inquiry-based activities to be successful, students need the time to explore. The amount of content in the curriculum needs to reflect the desired pedagogy. Curriculum planners will have to decide what concepts are core topics rather that insisting that the teachers cover all concepts presently mandated. This issue is fundamental to the second principle of how students learn. Factual information is essential for students to develop an understanding of the concept. If too much content is placed in the curriculum, teachers will avoid using inquiry-based activities in order to address the required material.

Inquiry-based experiments are challenging to develop. Bencze and Di Giuseppe looked at the laboratory activities that the science teachers were using in their classrooms. Rather than use laboratory sessions that promoted science inquiry, the students were given activities that focused on technological designs (inventions) and laboratory sessions that were teacher-directed and closed-ended. The authors' rationale was that "these teachers preferred to preserve the integrity of professional science and its products (laws and theories)" (Bencze \& Di Giuseppe, 2006, p. 347). Teachers were worried that students with misconceptions would continue to explore and look for evidence that proved their misconceptions true rather than revise their theory towards the scientifically proven truth. Secondly, many teachers felt that some students left on their own path may become distracted and off-task. Reflecting back on principle one of how students learn, it is important to address the students' misconceptions. Some theories in science are very complex. A more teacher-instructed approach may help direct the students through their misconceptions rather than having them spend hours trying to disprove their views.

Egan in his article, "Competing voices for the curriculum" (1966), discusses how the influences of different "stakeholders" in education can direct the curriculum. In the case of the Ontario school, the stakeholders that resisted the inquiry-based laboratory sessions were the students and the parents. "Ninth grade students at 
Beaverbrook seemed to have deeply ingrained expectations that it was a teacher's job to regulate their learning" (Bencze \& Di Giuseppe, 2006, p. 352). Students were concerned that they would not "learn anything" and "get frustrated" using inquirybased laboratories. They preferred the more teacher-directed approach and instruction-based laboratories. Parents of Beaverbrook students were concerned about the level of academic standards their children would receive in a less-guided environment. They too promoted a more didactic and teacher-led class.

When reflecting back on the book Teaching Inquiry-Based Chemistry, I too had many reservations and questions regarding inquiry-based labs such as the soap lab. Can I fit these types of laboratories into a busy content-based curriculum? What do I do with students who get off track conceptually with the lab or are socially distracted or disinterested? How do I explain spending so much time on one concept to my administration, and parents? How do I go about designing an inquiry-based lab that challenges students yet is possible to do in the classroom? These questions and doubts may make it challenging for a teacher to feel confident implementing inquiry-based laboratories in their classroom.

\section{Conclusion}

As in Egan's article there are two opposing views as to how science should be taught. If one focuses on viewpoints of the different stakeholders-parents, students, teachers, school boards, etc.- -it is difficult to make any decisions about the best teaching approach. Egan believes that we must look at the differences in viewpoints in terms of theories of pedagogy before we can discuss the issues. Bencze and Di Giuseppe state that the issues about inquiry-based education stem from opposing views of science education.

It is apparent to us that the resistance residing in these various entities indicates the existence of at least two opposing ideological camps; that is, a collection of people whose views about education largely place students in the role of knowledge consumers and those who believe that education should-in addition to knowledge consumption-involve significant knowledge production by students (Bencze \& Di Giuseppe, 2006, p. 355).

It has been argued that inquiry-based science is a method of pedagogy that allows the student to be a "knowledge producer" in the class. This teaching approach 
addresses the three principles of how students learn science. However, the amount of content in most science curriculum places students as "knowledge consumers."These opposing view place teachers in a difficult predicament.

Gallagher-Bolos and Smithenry argue that the teacher can work through these opposing views. They do not promote an entire curriculum devoted to inquirybased laboratories but suggest integrating small inquiry-bases activities throughout the year. These laboratories are intertwined by didactic lessons and teacher-directed activities.

An international symposium was held in 2002 which discussed inquiry in science education (Abd-El-Khalick et al., 2004). There were two suggestions that arose from this discussion that may help teachers in Quebec. The first proposal stated it was imperative to provide education for teachers on inquiry-directed laboratories:

Most science teachers have never directly experienced authentic scientific inquiry during their education in the sciences or within teacher education programs ... Teachers need to be well versed in scientific inquiry as a teaching approach, a set of process skills, and a content area" (Abd-El-Khalick et al., 2004, p. 404).

When mandating this new curriculum, our government must support teachers with instruction on how to design and use inquiry-based experiences effectively. Secondly, teaching inquiry may not always require an inquiry-based laboratory. The authors suggest that students perform a more teacher-directed scientific investigation and follow this laboratory with reflective journal writing about their understanding of the laboratory. According to the authors there is empirical evidence which demonstrates that this form of pedagogy will help students improve their concept of scientific inquiry (Abd-El-Khalick et al., 2004).

In conclusion, teachers should be encouraged to use inquiry-based activities in their science classes. Learning of science and higher-level thinking is promoted when students are pushed to develop their own understanding, when they have to think as scientists. However, it is important when writing a high school science curriculum that mandates inquiry-based laboratory sessions that the content in the curriculum be lowered to respect the time need for such inquiry. Teachers will struggle if the content is too demanding for an inquiry-based approach. When this is the situation, it is the inquiry-based laboratories that are eliminated, not the content. 


\section{References}

Abd-El-Khalick F., et al. (2004). Inquiry in science education: International perspectives. Science Education, 88, 397-419.

Bencze, J., \& Di Giuseppe, M. (2006). Explorations of a paradox in curriculum control: resistance to open-ended science inquiry tin a school for self-directed learning. Interchange, 37(4), 333-336.

DeHart-Hurd, P. (1997). Inventing science education for the new millennium. New York: Teachers College Press.

Donovan, S., \& Bransford, J. (2005). How students learn: History, Mathematics and Science in the classroom. Washington, DC: The National Academies Press.

Egan, K . (1966). Competing voices for the curriculum. Retrieved November 20, 2008, from http://www.educ.sfu.ca/kegan/Com petingvoices.html.

Gallagher-Bolos, J., \& Smithernry, D. (2004). Teaching Inquiry-Based Chemistry. Portsmouth, $\mathrm{NH}$ : Heineman.
Ministry of Education, Sports and Leisure (2008). Chemistry (Third year of cycle secondary cycle two) Validation Document. Quebec, QC: Ministry of Education.

Ogan-Bekirouglu, F., \& Sengul-Turgut, G. (2008). Does constructivist teaching help students move their epistemological beliefs in physics through upper level? Paper presented at the Conference of Asian Science Education.

Olson, S., \& Loucks-Horsley, S. (2000). Inquiry and the National Science Education Standards: A Guide for Teaching and Learning. Retrieved November 17, 2008, from http://www.nap. edu/catalog.php?record_id=9696.

Parsons, M. (2004). Art and integrated curriculum. In Elliot W. Eisner and Michael D. Day (Eds.) Handbook of research and policy in art education. Manwah, NJ: Lawrence Erlbaum Associates.

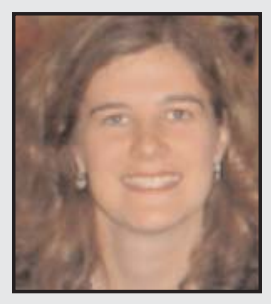

Marguerite Comley (B.Sc. Dip.Ed.) is the Department Head of Science at Lower Canada College in Montreal. She has been teaching for the past 13 years in both the public and private sectors. She is an M.A. candidate in Curriculum Studies at McGill University. 